\title{
O CAPITÃO E A SEREIA: PERCURSOS E SENTIDOS
}

Mona Magalhães ${ }^{1}$

Doutora em Estudos de Linguagem

mona.magalhaes@gmail.com

\begin{abstract}
Meus olhos boiaram por diversas vezes. Arrepiei-me inúmeras vezes. Mas calafrios no calor pode ser brisa na praia. Não era miragem. Eu estava em terra firme acreditando em tudo que via. Não tenho muita propriedade para falar sobre o fazer teatral. Mas sei sentir (NEVES, 2009).
\end{abstract}

Sentir! Percepção fundamental tanto na construção quanto na observação de um espetáculo. Sentidos aflorados em ambos os lados: no palco e na plateia. No palco, há um mundo, estrategicamente criado para que se façam emergir os campos perceptivos presentes nos dois lados, um universo que "vem assaltar e investir a subjetividade, assim como as ondas envolvem um destroço na praia"(MERLEAU-PONTY, 2006, p. 280). No ensaio em tela, traça-se um paralelo entre o processo de criação e os percursos geradores de sentido, em seus aspectos semióticos, do espetáculo teatral 0 capitão e a sereia, do Grupo Clowns de Shakespeare, de Natal, Rio Grande do Norte.

No meio de uma crise interna, poder-se-ia dizer que à deriva, Camille Carvalho, César Ferrário, Fernando Yamamoto, Marco França e Renata Kaiser, componentes do grupo potiguar, procuravam por textos para uma nova montagem teatral quando se depararam com o livro infantil de André Neves. Apesar de não ser um texto escrito especificamente para o teatro², mas uma literatura destinada às crianças, o grupo percebeu que a história do Capitão Marinho, escrita por Neves, seria uma ótima bússola para aquele momento, até mesmo para retratar o conflito que então viviam como

\footnotetext{
1 Doutora em Estudos de Linguagem - UFF, Mestre em Ciência da Arte - UFF, Bacharel em Artes Cênicas - Unirio. Especialista em Maquiagem pela Los Angeles School of Makeup (Revalidado pela Unirio). Responsável pela disciplina de caracterização na Escola de Teatro da Unirio. Desenvolveu trabalhos de caracterização para diversos espetáculos e grupos teatrais, entre eles: Grupo Galpão (MG), Clowns de Shakespeare (RN), Sertão (PB).

${ }^{2} \mathrm{~A}$ escolha por textos narrativos, romances, documentos históricos, entre outros, é uma das características do teatro contemporâneo, assim como a criação coletiva.
} 
grupo. O personagem principal, capitão Marinho, de acordo com o autor, nasceu e criou-se ouvindo histórias sobre o mar. Assim, ele se torna um contador de histórias e acaba por seguir em busca do sonhado mar e, a partir daí, começa uma nova vida. Ao encontrar uma sereia, acompanha-a num mergulho, que é a fusão do sonho com a realidade. Num primeiro momento, Marinho fica encantado, no entanto acaba por perceber que aquele não é seu lugar.

A história do capitão Marinho, que deixa a trupe, fazia uma justaposição com 0 abandono, sofrido pelo grupo, de três componentes. Dessa forma, ao levar a história escrita por Neves para 0 palco, o grupo Clowns de Shakespeare, subverte o foco narrativo da história e mostra em cena, os atores da trupe fictícia "Tropega mas não escorrega" que ficou à espera do capitão. Fernando Yamamoto, diretor do espetáculo, explica que o fio condutor é a luta de atores mambembes para que o público não perceba as circunstâncias em que se encontram, a da espera do líder deles. Num outro plano narrativo, os atores do grupo Clowns de Shakespeare comentam a situação de seus personagens e estabelecem um diálogo com a obra literária original.

Independentemente da estética teatral, numa encenação, encontram-se diversos sistemas expressivos que se relacionam num tempo e num espaço determinados (PAVIS, 2003, p. 21). Com base nessa premissa, parte-se para verificar como tais sistemas se articulam na encenação do grupo Clowns para $O$ capitão e a sereia. Pois bem, começa-se pela questão espacial, categoria topológica, do plano da expressão de uma linguagem artística. Categoria na qual se analisam a distribuição de formas, de cores, de texturas, de luzes, as iterações e os contrastes plásticos, visuais e sonoros, recursos capazes de criar categorias significantes agregadas a significados que fazem um espetáculo cênico existir como um todo de sentido. Cabe esclarecer, em outras palavras, que o teatro faz parte de uma semiótica sincrética, em cuja expressão se articulam diversas linguagens artísticas ou sistemas significantes, como prefere Patrice Pavis. Com base nisso, verifica-se que, no espetáculo em análise, há dois espaços definidos: o exterior e o interior. A encenação inicia-se com os atores do lado de fora do teatro, no tempo do agora, recebendo o público: conversam, brincam, até que começam a explicar as regras do jogo. Deixam claro que o que vai imperar no espaço interno, é a imaginação. 


\section{Cena I-Prólogo}

(Na parte externa do espaço de apresentação, entram os atores. Em seguida, falam aos presentes.)

MARCO - "Oh! Tivesse eu uma musa flamejante que ascendesse aos céus mais resplandecentes da invenção!" (William Shakespeare, dramaturgo inglês).

CAMILLE - "A imaginação é mais importante que o conhecimento". (Albert Einstein, físico alemão).

CÉSAR - "Imaginação é uma faculdade ou capacidade mental que permite a representação de objetos segundo aquelas qualidades dos mesmos que são dadas à mente através dos sentidos". Vou ler de novo: "Imaginação é uma faculdade ou capacidade mental que permite a representação de objetos segundo aquelas qualidades dos mesmos" - dos objetos, no caso - "que são dadas à mente através dos sentidos". (Jean Paul Sartre, filósofo e escritor francês).

RENATA - A imaginação é positivamente aparentada com 0 infinito -Charles Baudelaire -, e cresce através do exercício - Paul McCartney.

MARCO - Eu sou um gigante (Ana Clara, cidadã, brasileira, três anos, minha afilhada).

CAMILLE - Imaginar: Pelo "Dicionário Houaiss da língua Portuguesa", formar imagem mental de algo não presente. Pelo Aurélio, crer sem fundamento.

(Pausa.)

RENATA - Imaginação! Matéria-prima do teatro pré, pós ou simplesmente teatro. Viajaremos pelo sertão, sem o sertão. (Sai.)

CAMILLE - Digo mais: viajaremos pelo mar, sem o mar. (Sai.)

CÉSAR - Pior ainda! Viajaremos pela vida de um personagem, e aviso aos navegantes, até ele está faltando. (Sai.)

MARCO - Por isso, senhoras e senhores, que aqui terão a responsabilidade de cumprir o papel de público, já que eu, ao exercer o meu ofício, cumpro o papel de ator, convido todos a imaginar. Viajemos juntos! Permitam que, diante dos seus olhos, eu me transforme, sem truques, num personagem. (Vai colocando o chapéu. Para um instante) Isso aqui vai ser uma pechincha, pois como diria George Curtis, a imaginação vale muitas viagens e é mais barata.(Coloca o chapéu.)

Antes de mergulhar no oceano imaginário que estava prestes a emergir no interior do teatro, recorre-se a Anne Ubersfeld (2005, p. 115) que explica que o espaço cênico é duplo, uma dicotomia palco/plateia. Porém, no espaço externo da referida peça teatral, não há essa divisão de uma forma explícita, uma vez que os atores se espalham e se misturam com o público. No entanto ela se estabelece no interior do teatro, onde o público é direcionado aos lugares: à direita ou à esquerda do espaço delimitado por uma lona (Fig.1), completamente remendada e detalhadamente pintada, revelando uma espécie de mapa com o encontro da terra seca, expressa na cor marrom-amarelada e nos variados remendos; e do mar, expresso pelas formas curvas, pela cor azul, por alguns peixes e pela rosa dos ventos, pintados sobre ela. César Ferrário, em conversa, descreve-a em minúcias: 
[...] a lona tem formato elipsoidal, sendo aparada nas duas extremidades por dois cortes retos e paralelos. É uma lona velha, já bastante remendada, o que contribuiu para a textura final obtida. Nela temos desenhado um grande mapa de lugar nenhum, trata-se de uma geografia fictícia elaborada apenas no imaginário. Nesse grande mapa é possível identificar três tipos de superfície: terra e água, que dividem a maior parte de sua extensão, e próximo a uma de suas extremidades, uma pequena ilha de gelo. Todo esse mapa é perpassado por traços e linhas que sugerem paralelos e meridianos. Esse traçado converge para o centro da ilha congelada, como uma rosa dos ventos, mas sem definição dos cardeais. Espalhadas pelo mapa várias figuras que povoaram o universo da montagem do espetáculo "O capitão e a sereia", algumas verídicas e outras pertencentes à fábula. Cito algumas delas: Che Guevara de pé; o nosso barracão de trabalho; uma tribo carregando uma pessoa em direção ao cume de um vulcão, sugerindo um sacrifício; um pescador remando o seu barquinho; um farol; marcianos descendo do seu disco voador; o velho Shakespeare observando de longe o que se passa; Fernando, nosso diretor, sentado em uma cadeira com seu bloco de anotações em punho; Lampião e Maria Bonita posando para uma foto, entre outros.

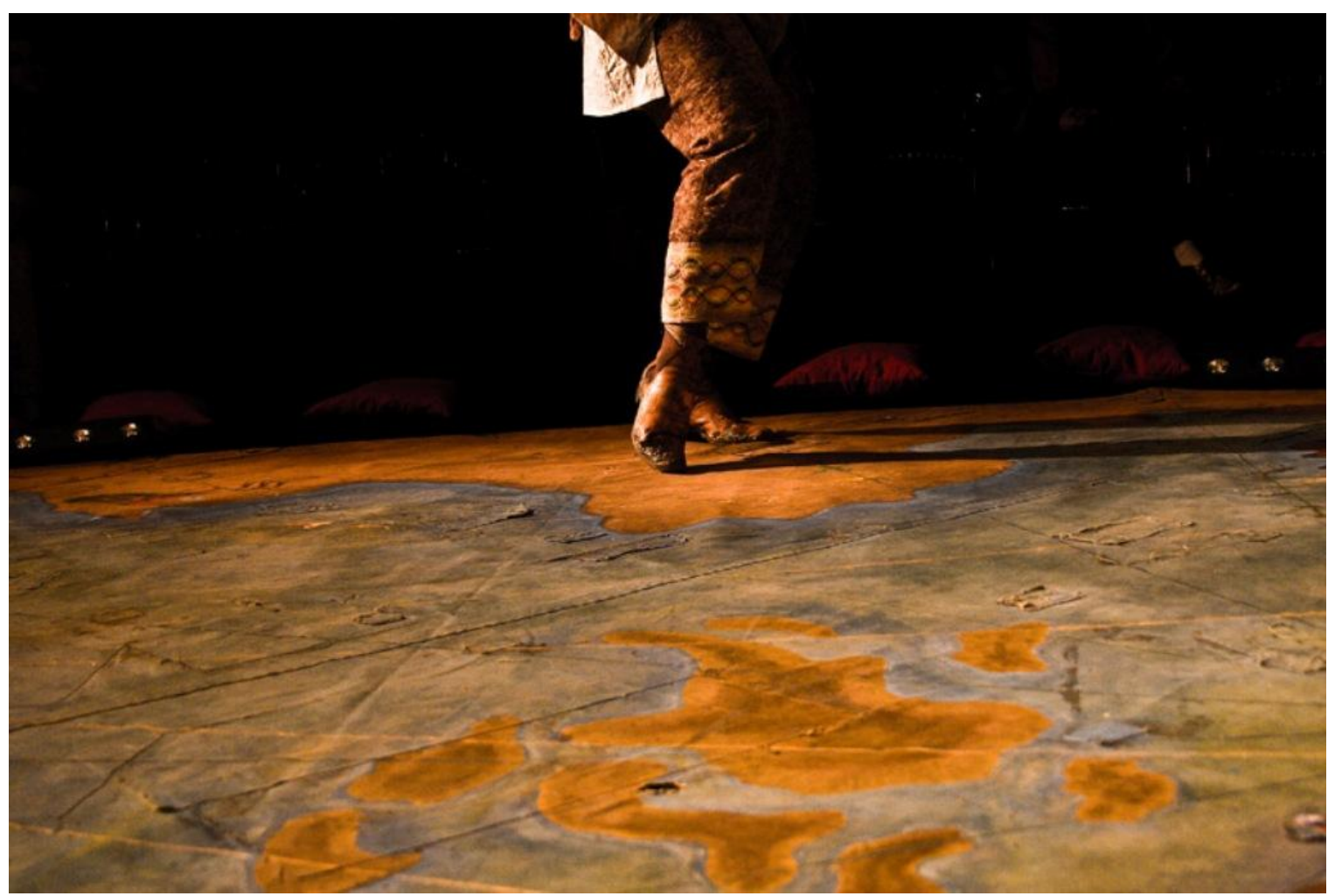

Figura 1: Detalhe da lona que delimita o espaço cênico de 0 Capitão e a sereia.

Fonte: Grupo Clowns de Shakespeare.

Retoma-se, agora, o acesso ao interior. Desse modo, ao entrar no teatro ${ }^{3}$ os espectadores, além de se depararem com os atores da trupe fictícia "Tropega mas não escorrega", precisam escolher

\footnotetext{
${ }^{3}$ Cabe ressaltar que se trata de referência ao teatro no qual o grupo estreou o espetáculo: Sesi Vila Leopoldina. Pode ser que, nas apresentações em outros teatros, o espaço destinado ao público tenha sofrido alguma modificação.
} 
em qual lado desejam assistir ao espetáculo, porém não podem atravessar a lona (terra e mar) e, sim, contorná-la pelas laterais. Tudo isso é embalado por um baião tocado ao vivo pelos personagens musicais que compõem a trupe.

No lado externo, os sistemas significantes que haviam sido colocados à disposição dos espectadores eram os atores maquiados e vestidos com uma roupa-base: blusa azulada e bermuda no mesmo tom para as atrizes; e calça, camiseta ou bata para os atores. Nesse momento, ainda não havia personagens, eram os atores por eles mesmos, porém preparados para atuar: Marco, Camille, César e Renata. A maquiagem, criada por Mona Magalhães (2010), nessa ocasião, já revelava o preparo para a cena, mas ainda não era possível compreender o sentido que tomaria na articulação com o espaço e o figurino. Não havia um espaço definido, não havia música, não havia luz. Havia as conversas entre atores e público; depois, o texto proferido por eles: a princípio uma enunciação enunciva que se constrói com o ele, o alhures e o então: há, pois, ausência da primeira pessoa (eu), somente se apresentam as palavras ditas por outros (Shakespeare, Einstein, Sartre, Baudelaire, McCartney, Houaiss, Ana Clara, Aurélio), produzindo um efeito de objetividade. A seguir, aos poucos, os atores começam a projetar-se na enunciação, fazendo uma debreagem enunciativa, quando o eu é colocado no interior do discurso: "Digo mais!" "Viajaremos..." "Já que eu, ao exercer o meu ofício..." frases que produzem um efeito de subjetividade e uma aproximação com o enunciatário que deve cumprir o papel que lhe cabe: 0 de público.

A partir daí, no aqui instalado no interior do teatro, os outros sistemas significantes também assumem seus papeis no oceano sincrético da encenação: o espaço cênico, a música, os figurinos, a maquiagem, a iluminação, a direção e a atuação. Assim, ao entrar no teatro, ouve-se as batidas fortes do baião, tocadas pelos próprios atores, vê-se a lona pintada, que revela mar e terra, e que delimita o espaço cênico, além das cadeiras destinadas ao público. Avistam-se os atores caracterizados (Fig.2 e Fig.3) de Antônio Curió (Marco França), Giulieta Esperanza (Renata Kaiser), Teobaldo (Cesar Ferrário) e Josefina Tililina (Camille Carvalho). Os figurinos agora vestem os personagens: Curió usa botas surradas, calça marrom com a barra bordada, camisa clara, colete marrom, rústico e enfeitado com debruns. Nas costas, o debrum toma a forma de espinha de peixe, uma espécie de colete de vaqueiro marítimo no meio do sertão. Teobaldo usa sandálias artesanais nordestinas, tem calças claras, de tecido rústico com franjas nas pernas, como a de pescadores; uma camiseta de malha clara de aspecto 
encardido; colete texturizado em tonalidades marrons, mais leve que o de Curió, e tem perneiras marrons e cinturão de treliça nas cores cáqui e marrom, adereçado com três chocalhos de vaca, distribuídos simetricamente na parte de trás. Usa, também, um grande rufo de aspecto encardido que Ihe dá uma aparência mais triste/romântica, à la pierrot. A maquiagem dele igualmente ressalta a característica melancólica, com traços que descem pela própria expressão do ator; e também remete ao sertão e traz a cor branca e a marrom- avermelhada. A forma do nariz, mais reto e largo, recorda as ilustrações do livro de referência, assim como a maquiagem de Curió, que também apresenta as mesmas cores e um formato de nariz em alusão aos desenhos dos personagens da trupe.

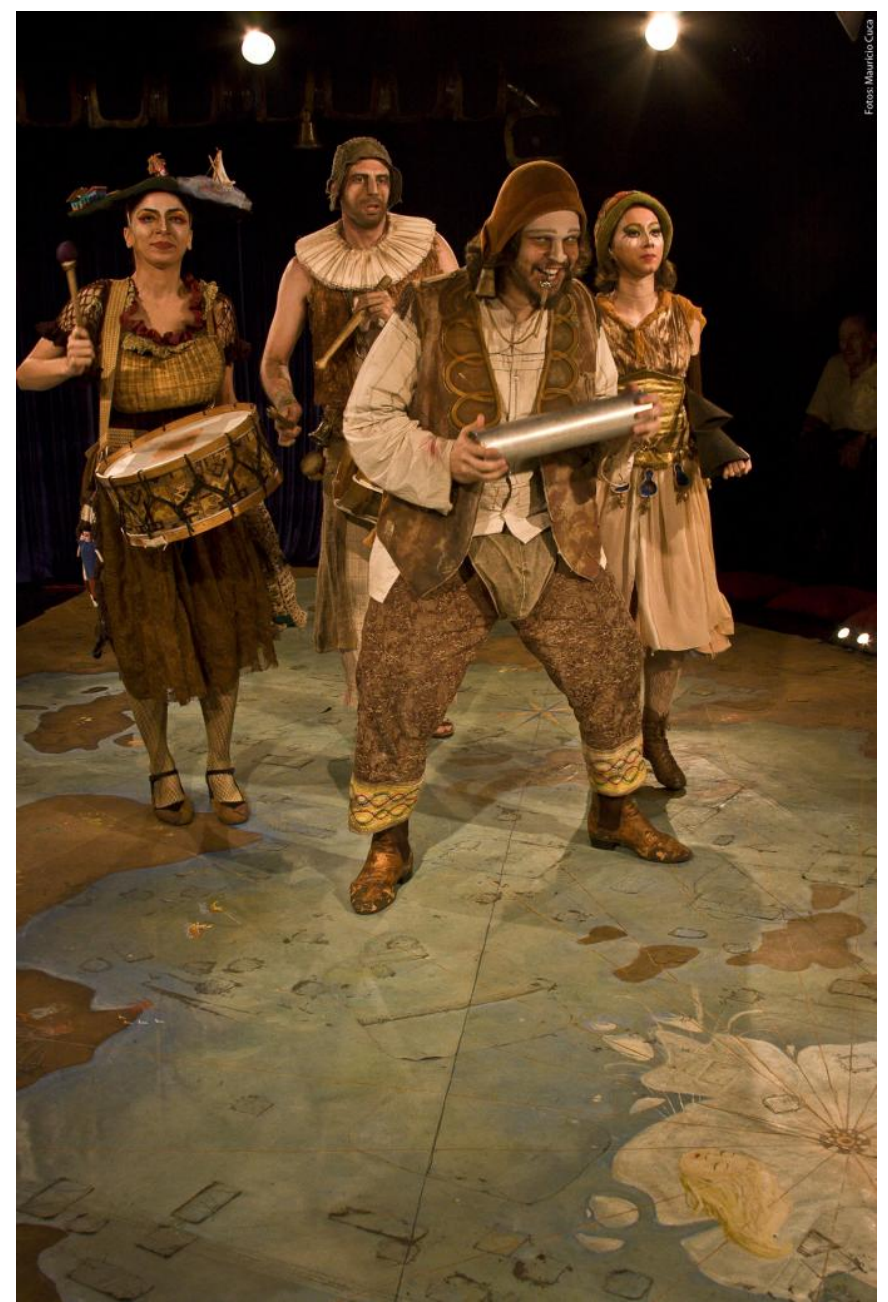

Figura 2: Personagens e atores: Giulieta Esperanza (Renata Kaiser), Teobaldo (Cesar Ferrário), Josefina Tililina (Camille Carvalho) e Antônio Curió (Marco França)

Fonte: Grupo Clowns de Shakespeare. 
A dupla feminina - Giulieta e Josefina - usa vestido: o da primeira tem duas colorações vinho e ocre - e é enfeitado com babadinhos e redes que lembram as de pesca. Vale ressaltar 0 detalhe que reveste a frente do vestido: a metade de uma bolsa de vime. Josefina tem o vestido mais leve, em tonalidades amarela, ocre e creme. A cintura é adornada por pequenas cabaças cortadas ao meio, cujo interior é pintado com motivos marítimos, em referência à ideia de pequenos relicários que guardam histórias e segredos sobre o mar, cada uma diferente da outra. A parte externa da cabaça é crua, como cascas a proteger o conteúdo interno, e a interna é cheia de pequenos e delicados desenhos. Os guizos dão o toque final. Na maquiagem, exploram-se as cores e algumas formas de peixes, como as linhas dos olhos de Josefina. Todos os figurinos e a maquiagem lembram o sertão com detalhes salpicados de elementos marítimos. Os figurinos, criados por Wanda Sgarbi, relacionam-se diretamente com o espaço e situam a origem da trupe, sem deixar de remeter ao sonho do líder ausente.

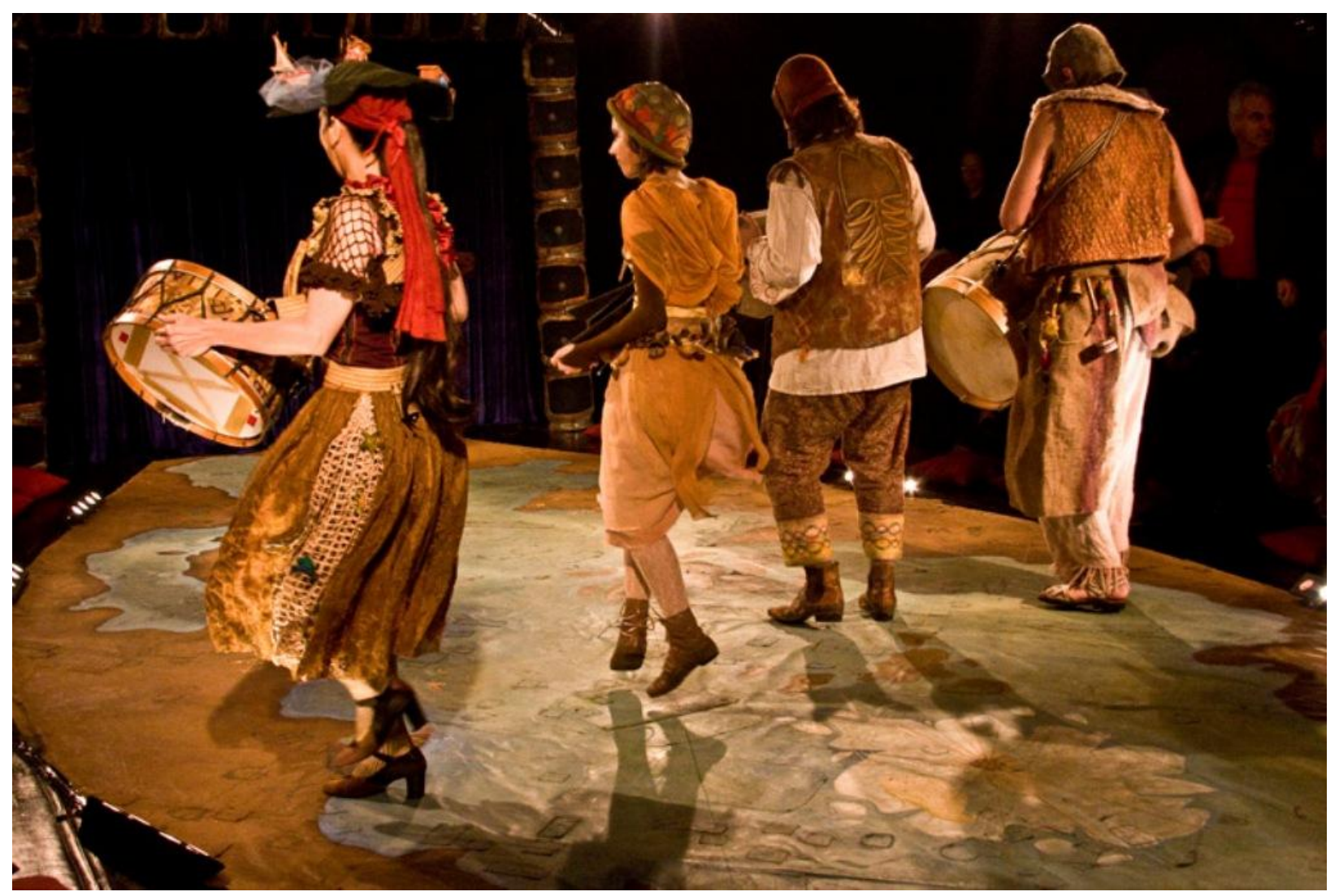

Figura 3: Figura 2: Personagens e atores: Giulieta Esperanza (Renata Kaiser), Josefina Tililina (Camille Carvalho), Antônio Curió (Marco França) e Teobaldo (Cesar Ferrário).

Fonte: Grupo Clowns de Shakespeare. 
Mas é necessário destacar a importância de uma peça comum ao figurino desses quatro personagens: o chapéu. $O$ de Josefina lembra um dos personagens que ela interpreta e tem a forma de um casco de tartaruga, com domos elevados, mas também alude ao sertão, com pequenos cactos decorando as bordas; Giulieta leva sobre a cabeça um chapéu que surgiu com base em uma das imagens mais significativas do livro de Neves, que retrata habitantes de uma cidade do sertão com casas nas cabeças, numa representação simultânea da gente e da arquitetura sertaneja. E, ainda, traz o mar e uma embarcação. $O$ chapéu de Curió tem a coloração marrom-avermelhada, dois chocalhos de vaca pendurados em cada ponta e posiciona-se sobre as orelhas; 0 de Teobaldo é puxado para um verde-musgo. Cada um dos chapéus irá representar o respectivo personagem no decorrer da peça. É, por meio deles, que o público embarca no jogo personagem/ator. O espectador compreende o jogo dos atores/personagens estabelecido pelo uso ou não dos chapéus. Quando a figura em cena está usando chapéu, é o personagem; quando não, é o ator. Do mesmo modo, quando se dispõem os chapéus no chão e os atores se afastam, a figura do chapéu permanece tendo o sentido do personagem. Isso se verifica, principalmente, no final do espetáculo, quando se colocam todos os chapéus no chão, lançamse sobre eles focos de luz, todos os atores se vão, e os personagens permanecem ali, no espaço cênico.

Toda essa figuratividade, disposta nos figurinos, na maquiagem, nos chapéus e no espaço, estabelece significação para que se perceba o mundo por meio dos cinco sentidos: visão, tato, olfato, audição e paladar. A recorrência das figuras - cabaças, chocalho de vaca, Lampião e Maria Bonita, remendos na lona, colete de vaqueiro, entre outras - corresponde ao conteúdo realidade/sertão. A presença das figuras - espinha de peixe, rufo, redes, rosa dos ventos, calça de pescador, embarcação, entre outras - correlaciona-se com o conteúdo sonho/mar. São isotopias figurativas que asseguram a coerência semântica e permitem "observar a permanência de um efeito de sentido ao longo da cadeia do discurso" ( BERTRAND, 2003, p.153). As isotopias responsabilizam-se, desse modo, pela unicidade de significação e a homogeneidade dos significados, observadas, nesse caso, pela originalidade com que as figuras se articulam e pela redundância durante a encenação.

Além das isotopias figurativas, na encenação há também uma variação isotópica, como a que acontece no vídeo apresentado durante as tentativas da trupe fictícia de distrair o público para que ele não perceba o grande problema que é a ausência do capitão Marinho. Apresenta-se o vídeo como um 
documentário acerca dos animais marinhos, porém as imagens exibidas são de vídeos, filmes famosos, desenhos animados e personalidades. Faz-se uma bricolagem de vídeos, na qual a figura do ser humano se destaca em situações limites ou bizarras ou ainda divertidas. O riso do público dá-se por causa de duas isotopias: a do texto falado — reprodução dos peixes; e a do texto visto — situações humanas. Há a leitura que se ouve da narrativa da primeira isotopia e que se contrapõe à segunda isotopia do que é visto. Dois sentidos - audição e visão - trabalham simultaneamente, porém possibilitando sentidos contrapostos. Segue a reprodução do texto narrado e a correspondência das cenas da bricolagem de vídeos:

\begin{tabular}{|c|c|}
\hline Texto & Vídeo \\
\hline $\begin{array}{l}\text { Nos mares do hemisfério norte, mais precisamente na } \\
\text { Espanha, podemos encontrar as mais raras espécies de } \\
\text { peixes hibridos. Estes seres caracterizam-se por passarem } \\
\text { parte se suas vidas em águas salgadas e, posteriormente, } \\
\text { como se estivessem cansados da vizinhança, pegam suas } \\
\text { coisas e partem para os rios ou alguma outra paisagem de } \\
\text { água doce. }\end{array}$ & $\begin{array}{l}\text { Cenas do documentário da BBC servem de base para todo } \\
\text { o vídeo, e todas as outras imagens entram como rápidas } \\
\text { sobreposições. } \\
\text { Cenas de touradas. } \\
\text { Cenas de partida. }\end{array}$ \\
\hline $\begin{array}{l}\text { Esse estranho ser Marinho, capaz de viver em ambientes } \\
\text { tão distintos, foi visto pela primeira vez pelo pesquisador e } \\
\text { explorador espanhol Manélios Scott. Em uma de suas } \\
\text { campanhas exploratórias, Manélios acampava na beira de } \\
\text { um rio quando decidiu preparar uma refeição e, quase que } \\
\text { instantaneamente, o estranho ser marinho pulou dentro da } \\
\text { sua frigideira. }\end{array}$ & $\begin{array}{l}\text { Cenas gravadas } \\
\text { 1. Manélios deitado à beira de um rio e um peixe cai dentro } \\
\text { de sua frigideira. } \\
\text { 2. Manélios diante de um peixe frito. }\end{array}$ \\
\hline $\begin{array}{l}\text { Para entendermos um pouco mais sobre esse fenômeno, } \\
\text { vamos nos ater aos hábitos desse Ser. Ele se submete a } \\
\text { um verdadeiro suicídio para evitar que a sua espécie se } \\
\text { extinga. E é capaz de ultrapassar vários obstáculos e o } \\
\text { limite do cansaço para voltar ao leito do rio onde nasceu e } \\
\text { se criou, com o objetivo único de desovar. Quando alcança } \\
\text { a maturidade, um misterioso instinto o empurra para fora do } \\
\text { mar, na direção do rio. Então, entre os meses de setembro } \\
\text { e novembro, começa uma viagem sem volta. }\end{array}$ & $\begin{array}{l}\text { Limites do cansaço: Clássica cena do final da corrida da } \\
\text { maratonista olímpica que ficou em último lugar. } \\
\text { Objetivo único de desovar: Quero Ficar com Polly - } \\
\text { 2004. Cena do sanitário. Ou Monty Python, O Sentido da } \\
\text { Vida, cena do parto. } \\
\text { Um ano, sete anos: Cenas de crescimento. } \\
\text { Forrest Gump, a pequena loja dos horrores. } \\
\text { Misterioso instinto: Cenas de masturbação } \\
\text { Jornada: Forrest Gump, Coração Valente, Senhor dos } \\
\text { Anéis, Pearl Harbor, Kung fu Panda. }\end{array}$ \\
\hline $\begin{array}{l}\text { A partir do momento em que sai do mar e entra na água } \\
\text { doce, ele não come mais. Sua obsessão é chegar. Esse } \\
\text { teste de resistência só termina quando finalmente ele } \\
\text { aporta em seu berço natal. Com as nadadeiras aos } \\
\text { pedaços, magro e faminto, ele cumpre sua missão. } \\
\text { Sessenta dias depois, os filhotes nascem. Completada a } \\
\text { tarefa, resta ao Ser Marinho deixar-se levar vagarosamente } \\
\text { rio abaixo e ir ao encontro da morte. }\end{array}$ & $\begin{array}{l}\text { Berço natal: Chegada. } \\
\text { Desovar: Cenas de amor e prazer. }\end{array}$ \\
\hline & \\
\hline
\end{tabular}


Voltando aos figurinos, utiliza-se a classificação vetorial proposta por Pavis (2003, p. 168): em O capitão e a sereia, assim como em todos os espetáculos, os figurinos podem ser classificados como vetores acumuladores, vetores conectores, vetores secionantes e vetores embreadores. Vale ressaltar que, nem sempre, os figurinos correspondem a todos esses vetores. Porém, nesse espetáculo, eles são acumuladores por condensarem e/ou acumularem vários signos, como as redes, os debruns de espinha de peixe (isotopias do mar), as cabaças, os chocalhos de vaca, as sandálias artesanais (isotopias do sertão).

São vetores conectores, quando o público pode "ler uma roupa em relação às outras" (PAVIS, 2003, p. 168), e são facilmente identificados entre as roupas dos atores descritas acima e as roupas das personagens, também discriminadas anteriormente. Nesse caso, os chapéus são explorados nessa função vetorial de conexão com as personagens, uma vez que o público faz a leitura: quando as figuras em cena estão com o chapéu significa que são os personagens da trupe fictícia e não os atores do grupo Clowns de Shakespeare. Os chapéus, assim, são como metonímias que representam os personagens ao serem sob os respectivos focos de luz.

São vetores secionantes quando há mudança de aparência: nesse caso, a substituição de figurino nas cenas das páginas azuis, nas quais os atores trocam de roupa, à vista do público, valorizando a tonalidade citada. As atrizes vestem saias azuis de tecido leve e texturizado e mantêm as blusas-base que também são azuis; os atores igualmente colocam um elemento azul — Marco vira o colete pelo avesso que está pintado de azul, e César veste por cima da roupa-base uma espécie de saia que não da a volta completa ao corpo. Essa saia é verde-piscina, é feita de um tecido mole e de textura amassada. Sobre o tecido verde, há uma rede vazada na cor de sisal, como se fosse uma rede de pescador.

Por ser um "embreador natural entre a pessoa física e privada do ator e o personagem da qual ele veste a pele e os aparatos" (PAVIS, 2003, p. 168), os figurinos de 0 capitão e a sereia, assim como os demais, também exercem essa vetorização, e o espectador tem a dupla visão de como 0 ator manipula o figurino e de como o figurino se articula no sentido global da encenação.

O jogo personagem/ator tem três níveis bem determinados, que se foram construindo durante os ensaios: 

1) 0 ator que representa a si próprio.
2) O ator que representa um personagem da trupe.
3) O personagem da trupe que representa outro personagem.

Percebem-se esses níveis pela própria atuação, por meio dos figurinos cujas características já foram expostas acima e também pela iluminação. Ressalta-se que a iluminação é fundamental em um espetáculo cênico, pois é ela que o "faz existir visualmente" (PAVIS, 2003, p. 179). Além disso, ela pode conceder atmosferas aos atores, ao espaço, ao figurino e à maquiagem. Ronaldo Costa (2011), iluminador do referido espetáculo, elaborou uma luz que ressalta o jogo da atuação, ou seja, as luzes são trabalhadas em diferentes intensidades para cada nível de representação. Dessa forma, para os momentos em que os integrantes do grupo eram eles próprios, a luz apresentava-se na intensidade máxima, favorecendo o diálogo entre os atores e o público. A intensidade média era destinada para os personagens da trupe fictícia, e utilizavam-se a intensidade baixa ou os efeitos específicos para os momentos nos quais estavam em cena os personagens que a trupe interpretava. Desse modo, as relações enunciativas articulavam-se entre o modo de atuação, o espaço, os figurinos e a iluminação. Portanto, cada linguagem reitera a outra.

Porém cabe destacar o momento em que a luz se contrapõe à música em cena. Tal contraponto acontece na penúltima cena, denominada de páginas azuis. Nos primeiros momentos, acontece a materialização do mundo fantástico, criado pelo autor, que coloriu as páginas do livro de azul. Em cena, a luz e os figurinos reiteram-se num mundo azulado - uma cor fria que, além de propiciar a fantasia, suscita certa melancolia que revela o momento de crise do Grupo:

\section{Cena VII - Páginas azuis}

RENATA - Senhoras, senhores, caro público, vamos apresentar agora a nossa penúltima cena, chamada por nós de "Páginas azuis". É um momento muito delicado, pedimos o máximo da sua atenção a ela, pois tentamos em uma só cena colocar todos os questionamentos e dilemas que nos deparamos ao longo do processo de construção deste espetáculo, a maior parte deles sem qualquer pista de solução.

CAMILLE - 0 dramático ou o real?

CÉSAR - A representação ou a não representação?

$\mathrm{MARCO}$ - $\quad \mathrm{O}$ ator ou o personagem? 
RENATA - $O$ indivíduo que se sobressai ao coletivo, ou o coletivo que anula 0 indivíduo? Ou nenhuma das alternativas anteriores?

(Retomam as contações paralelas, do momento em que Marinho parte.)

CÉSAR - Marinho partiu em busca de outros mares. Foram quilômetros e quilômetros de jornada, muitas vezes errando caminhos e ficando completamente à deriva.

Nessa cena, um paletó, um binóculo, um chapéu e um garfo, manipulados pelas atrizes, representam o capitão Marinho e sua saga até encontrar o mar. E esse é o ponto ápice do espetáculo. É nesse momento em que nenhuma figura ou isotopia figurativa daria conta de dar leitura e transmitir a emoção do capitão ao visualizar, pela primeira vez, o tão sonhado mar. O grupo decide, então, retirar a visão do público, por meio de um efeito de luz, e levá-lo a navegar nos próprios mares, por meio da música.

(Cena azul. Meninos tocam instrumentos, enquanto meninas manipulam roupa e chapéu do Marinho.)

MARCO - Finalmente, numa manhã de sol, capitão Marinho encontrou o mar. Aquela imensidão azul se abriu diante dos seus olhos, e Marinho ficou estarrecido diante daquela imagem desejada por toda a sua vida. Diante daquela primeira visão do mar, Marinho não enxergou mais nada.

(Blecaute. Tema do Capitão.)

Retira-se o sentido da visão por um black-out de exatos três minutos, e aguça-se o sentido auditivo pela música denominada "Tema do Capitão", cujos acordes em tons menores conduzem a imaginação para o mar de cada um dos espectadores. A música tem uma inspiração direta de algumas canções pesquisadas durante o processo de construção, em especial a "Canção do mar", da Amália Rodrigues, com pitadas das músicas de Nino Rota para os filmes de Federico Fellini. O tema, composto por Marco França, é tocado ao vivo, com sanfona, clarineta, escaleta e metalofone (que é uma espécie de xilofone, mas com teclas de metal). O tom menor dá um clima melancólico, que sequencia o clima proporcionado pela luz da cena anterior. Contudo a melodia e a composição de instrumentos, em especial o metalofone, trazem um toque de leveza, com referências a circos e ao universo da imaginação da infância do capitão Marinho.

A ausência de imagens permite a invasão do mar no espaço que se torna único, e todos atores e público - mergulham num mar individual que é misturado pelas ondas sonoras ao mar de todos e, em especial, ao do capitão. $E$ todos esses mares se transformam no grande oceano cênico de 
O capitão e a sereia. Os estímulos proporcionados pela música criam uma envoltura sensorial que abarca todos os outros sentidos. Uma sinestesia com base na conexão geral e imediata de todas as sensações no único lugar: a música que conecta a visão imaginária do mar, a sensação tátil da água, o cheiro da maresia, das algas e o gosto salgado do mar. É nesse momento que o público e os destroços na praia, como relata Merleau-Ponty, são envolvidos sensivelmente.

Fontanille explica que "o sentido designa um efeito de direção e de tensão mais ou menos conhecível, produzido por um objeto, uma prática ou uma situação qualquer" (2007, p. 31). 0 objeto artístico em questão vai ocupando uma posição e uma extensão que afeta o espectador com certa intensidade e este pode resistir ou render-se a ele. $O$ foco intencional mede 0 afeto que toca e pode ser mais ou menos intenso. A apreensão do objeto pode ser mais ou menos extensa. Quando se analisa o sentido de um espetáculo teatral, deve-se considerar que ele significa em ato, no momento em que é apresentado. Desse modo, durante toda a encenação de 0 capitão e a sereia, o público vai apreendendo todas as figuras, todas as reiterações das linguagens artísticas, na extensão do espetáculo, de um modo inteligível. Contudo, no momento em que é retirado o sentido da visão e as ondas sonoras invadem a alma do espectador, uma surpresa que faz arrepiar, atinge o máximo da intensidade do foco afetivo. Até então, o público estava acostumado com todos os estímulos visuais e sonoros, porém a retirada do estímulo visual, de um modo geral ${ }^{4}$, proporciona 0 ápice da intensidade sensível.

O encadeamento e a sobreposição de atos unem a dimensão da intensidade (sensível) e a dimensão da extensão (inteligível). Antes do momento de visualizar o mar, havia um relaxamento cognitivo, um conforto para o público que apreendia as informações, um esquema descendente. Porém, no momento do longo Black-out, aumenta a intensidade sensível e há redução da extensão, do inteligível: um esquema de ascendência. Há, então, um movimento da diminuição da extensidade(figuras, espaço, cores, luz) para um de aumento da intensidade (sonora). Cabe esclarecer que, durante toda a encenação, esses movimentos acontecem em maior ou menor escala, contudo é preciso destacar esse momento por considerá-lo o ápice do espetáculo. Esse movimento pode ser representado nos seguintes esquemas tensivos:

\footnotetext{
${ }^{4}$ Se o público se entregar e não resistir. Não é uma regra, pode acontecer uma resistência, pois se trata de subjetividade.
} 

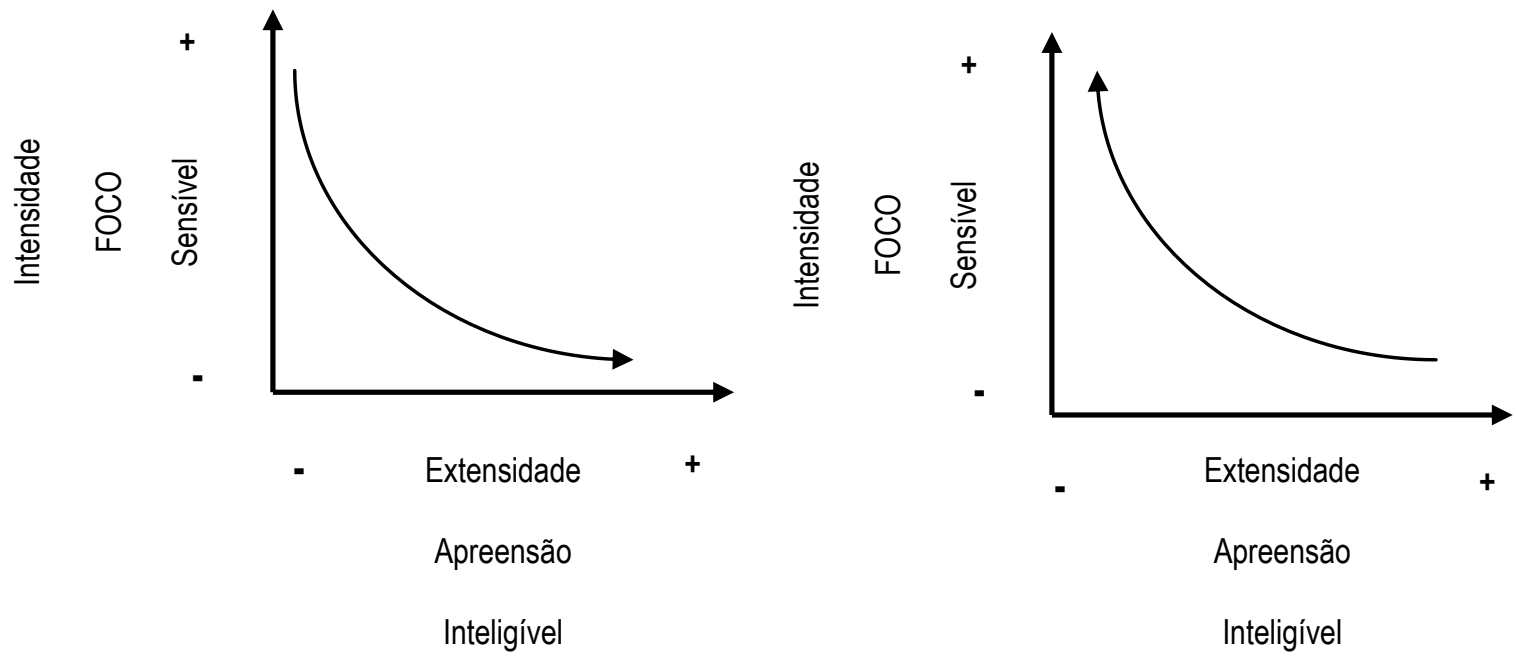

Assim, entre intensidades e extensões, entre visuais e sonoridades, entre presenças e ausências, entre calafrios e pensamentos, o espetáculo 0 capitão e a sereia segue mar afora levando com ele o público e os afetos, as emoções e as razões. "O sentido não é algo isolado" (FIORIN, 1999), surge de um conjunto de relações, das isotopias, das figuras, da música, da iluminação, das cores, das texturas, do espaço, dos atores, entre outros. Com base nas articulações é que se vão criando os efeitos estéticos, poéticos, verossímeis, objetivos e subjetivos, de ausências e de presenças, mais sensíveis ou mais inteligíveis. Conta-se a história do capitão Marinho com todos os recursos plásticos e sonoros possíveis, e o grupo Clowns de Shakespeare consegue, mesmo sem a anunciada presença do personagem principal, criar o efeito da presença dele - seja na manipulação dos elementos cênicos que formam um boneco Capitão à procura de si mesmo e de seu sonho, seja em cada um dos personagens da trupe: Giulieta, Curió, Teobaldo e Josefina, que permanecem no espaço cênico, representados pelos respectivos chapéus, prontos para receberem ou não o capitão; mas prontos também para, como as sereias, encantarem o público e levá-los a sonhar. Eles e os destroços, sem 
contudo estarem destroçados, mas sim reconstruídos pelo mundo fantasioso, envolvidos pelo oceano cênico, cientes das dificuldades, dos dilemas e das lutas do mundo real.

\section{REFERÊNCIAS}

BARROS, Diana Luz Pessoa. Teoria semiótica do texto. São Paulo: Ática, 2003.

BERTRAND, Denis. Caminhos da semiótica literária. Bauru: EDUSC, 2003.

COSTA, Ronaldo. A luz do Capitão. In: YAMAMOTO, Fernando; COSTA, Ronaldo; FERRARIO, Cesar et al. Revista Balaio. vol. 2. Natal: Clowns de Shakespeare, Nov. 2011.

FIORIN, José Luiz. Elementos de análise do discurso. São Paulo: Contexto, 2008.

FIORIN, José Luiz. Sendas e veredas da semiótica narrativa e discursiva. Delta [online] 15 (fev-jul 1999).

FONTANILLE, Jacques. Semiótica do discurso. São Paulo: Contexto, 2007.

MAGALHÃES, Mona. Maquiagem e pintura corporal: uma análise semiótica. Niterói: UFF, 2010. Tese. Doutorado. Discurso e interação, 236 ps.

MERLEAU-PONTY, Maurice. Fenomenologia da Percepção. São Paulo: Martins Fontes, 2006.

NEVES, André. 0 capitão e a sereia. Santo Amaro: Scipione, 2007.

Segundas impressões. In: Odiariodocapitao.blogspot.com. 2009. Disponível em: http://www.odiariodocapitao.blogspot.com. 21 de 10 de 2009. Acesso em: 21 out. 2009.

NOGUEIRA, Fernanda Ferreira Marcondes. Isotopia temática e figuratividade em "Eis os amantes" e "Intradução" de Augusto de Campos. Estudos Semióticos. São Paulo, vol. 3, 2007. 
PAVIS, Patrice. A análise dos espetáculos: teatro, mímica, dança, dança-teatro, cinema. São Paulo: Perspectiva, 2003.

TEIXEIRA, Lucia. A praxis enunciativa num auto-retrato de Tarsila do Amaral. In: Semiótica Plástica, por Ana Claúdia OLIVEIRA, 229-242. São Paulo: Hacker, 2004.

UBERSFELD, Anne. Para ler o teatro. São Paulo: Perspectiva, 2005.

YAMAMOTO, Fernando; COSTA, Ronaldo; FERRARIO, Cesar et al. Revista Balaio. vol. 2. Natal: Clowns de Shakespeare, Nov. 2011. 